\title{
Evaluation of ecological and genetic condition of Rivne city for Micronucleus Test
}

\author{
Igor Grygus ${ }^{1}$, Mariana Kaskyv ${ }^{1}$, Walery Zukow ${ }^{2 *}$ \\ ${ }^{1}$ Institute of Health Sciences, National University of Water and Environmental Engineering, \\ Soborna 11 St, 33028, Rivne, Ukraine, \\ ${ }^{2}$ Department of Spatial Management and Tourism, Faculty of Earth Sciences, Nicolaus Copernicus University, \\ Lwowska 1 St, 87-100 Toruń, Poland, \\ *e-mail: w.zukow@wp.pl
}

Received: 20 November 2017 / Accepted: 12 February 2018

\begin{abstract}
Bioindication evaluation of air condition in the city of Rivne has been carried out using the micronucleus (MN) test on the oral mucous in under-school-age children. The highest maximum values of MN indices were determined for children who live in the studied test ranges, where the content of $\mathrm{CO}$ (carbon oxide) exceeds the maximum permissible concentration. Cytogenetic indicators vary in a wide range of numerical values; moreover, the level of cytogenetic damage is an informative bioindicational feature.

With the monitoring purpose, the researched urban area of Rivne was divided into 12 test ranges with different anthropogenic load; a number of large and small manufacturing firms are situated there. The analysis of statistical and analytical data on the traffic intensity in the city was conducted. The study was also based on the analysis of personal researches, obtained through a comprehensive survey carried out on 167 children in 12 test ranges in 12 preschools, the average age of children was 6-7 years. A total of 64,950 mucosal epithelial cells were explored.

It has been shown that the deterioration of ecological and genetic conditions of the urban environment in test ranges I, II, VI, VII, VIII, XI based on the cell damage level was "below average", the condition of the children's organism was "alarming" but the state of the environment has changed from "excellent" to "satisfactory".

This kind of research can enable observations of the mutagenic background of regions, genetic health, and genetic threats to humans due to harmful factors.
\end{abstract}

Key words: epithelial cells, micronucleus test, cytogenetic damage, environment, bioindication, mucosa, epitheliocytes, CID.

\section{Introduction}

As a matter of fact, global pollution of the environment is caused by anthropogenic products, which are characterised by mutagenic activity, pollution influences people`s genetics and the immune system. The pollution of the biosphere components with harmful substances, the nascence of new chemicals, and increased radioactivity threaten the environmental condition, the health of the population and limit the further development of human society (Serdiuk,
1996; Tymchenko \& Serdiuk, 1996; Ministerstvo Okhorony Zdorovia Ukrainy, 2007; Klymenko \& Melikhova, 2001; Ballarian et al., 1992; Bender, 2002; Schlegel et al, 1986; Sladecek, 1973; Shirasu et al., 1982).

As a result, there is a necessity of solving such problems as: 1) control of the process of air pollution with mutagens in Rivne; 2) prevention of the growth of mutagenic pollution; 3) learning the nature of the mutagens' action; 4) searching the tools and methods of protecting living organisms from the negative impact. 
Methods of bioindication are used as a way of detecting anthropogenic impact on biocenose. They are based on a research on the variable environmental factors' impact on different characteristics of biological systems. Bioindicators are the most sensitive organisms. Results (changes in the behaviour of the test-object) are estimated in the comparison with the control areas, accepted as a standard (Ministerstvo okhorony zdorovia Ukrainy, 2007; Cairns, 1975; Chakrabarty \& Dutta, 1988; Goodnight \& Whitley, 1961; Gunneberg, 1992).

The purpose of the work is a clarification of the Rivne ecosystem condition in terms of cytogenetic monitoring.

\section{Materials and methods}

With the purpose of the monitoring researched area of Rivne city was divided into 12 test ranges with different anthropogenic load, a number of large and small manufacturing firms are situated there. The analysis of statistical and analytical data on the intensity of the flow of vehicles in the city was made. Also, the study was based on the analysis of the personal researches, obtained through a comprehensive survey of 167 children on 12 test ranges in 12 pre-schools, an average age of children was 6-7 years old. 64950 mucosal epithelial cells were explored.
None of the children have concomitant somatic diseases. Clinical study included an assessment of the data history, which was conducted by questioning. An obligatory condition of the study was to research children, who have been living on the test sites at least 4 years. Oral cavity of the preschool children was an object of the cytogenetic studies. Sampling of cells of the oral mucous membrane of children was conducted according to the permits, which were officially granted by the Department of Education and Science of the Rivne Regional State Administration.

Swabs of the oral mucous membrane were taken from the inside of the right and left cheeks, lower lip with the help of an individual spatula followed by putting on the glass slide. Condition of epithelial cells was evaluated by the method suggested by A. Gorovaya (Gorovaya et al., 1995; Gorovaya et al., 1996; Ministerstvo Okhorony Zdorovia Ukrainy, 2007; Feron et al., 2001; Gruter, 1971; Gunneberg, 1992; Grazuleviciene, 1995; Gluck \& Gebbers, 2000; Haseman \& Hailey, 1997; Horyna \& Randa, 1988).

MN-index was calculated from the frequency of cells with micronuclei per one cell (Ministerstvo okhorony zdorovia Ukrainy, 2007; Kuper et al., 1997; Nair, 1991; Nair et al., 1991; Pantle \& Buck, 1955; Rosin, 1992). The number of cells with secondary micronuclei characterises the degree of environmental pollution by mutagens

Table 1. MN-index of cells in oral mucous membrane of pre-school children of Rivne city

\begin{tabular}{|c|c|c|c|c|c|c|}
\hline $\begin{array}{c}\text { Researched } \\
\text { area }\end{array}$ & $\begin{array}{l}\text { Part of the } \\
\text { city }\end{array}$ & $\begin{array}{c}\text { Number } \\
\text { of people } \\
\text { in a group }\end{array}$ & $\begin{array}{c}\text { Total } \\
\text { number } \\
\text { of cells }\end{array}$ & $\begin{array}{l}\text { Maximum } \\
\qquad(x \pm a)\end{array}$ & $\begin{array}{l}\text { Minimum } \\
\qquad(\mathbf{x} \pm \mathbf{a})\end{array}$ & $\begin{array}{l}\text { Average } \\
(\mathbf{x} \pm \mathbf{a})\end{array}$ \\
\hline \multirow{2}{*}{$\begin{array}{l}\text { I - Makarova St } \\
\text { II - Verbova St }\end{array}$} & \multirow{2}{*}{ Northwest } & 12 & 4700 & $0.050 \pm 0.003$ & $0.010 \pm 0.001$ & $0.037 \pm 0.001$ \\
\hline & & 14 & 4700 & $0.045 \pm 0.003$ & $0.010 \pm 0.001$ & $0.033 \pm 0.002$ \\
\hline \multirow{2}{*}{$\begin{array}{l}\text { III - Konovaltsia St } \\
\text { IV - Haharina St }\end{array}$} & \multirow{2}{*}{ Northeast } & 14 & 5700 & $0.048 \pm 0.003$ & $0.010 \pm 0.001$ & $0.024 \pm 0.001$ \\
\hline & & 15 & 5850 & $0.040 \pm 0.002$ & $0.010 \pm 0.001$ & $0.025 \pm 0.002$ \\
\hline $\mathrm{V}$ - Dubenska St & Southwest & 14 & 6800 & $0.050 \pm 0.003$ & $0.006 \pm 0.000$ & $0.027 \pm 0.002$ \\
\hline VI - Hoholia St & Southeast & 19 & 8350 & $0.048 \pm 0.003$ & $0.013 \pm 0.001$ & $0.034 \pm 0.001$ \\
\hline VII - Lutovska St & Centre & 12 & 4650 & $0.050 \pm 0.003$ & $0.011 \pm 0.001$ & $0.028 \pm 0.002$ \\
\hline VIII - Vidinska St & Southeast & 14 & 5050 & $0.050 \pm 0.003$ & $0.010 \pm 0.001$ & $0.036 \pm 0.002$ \\
\hline \multirow{2}{*}{$\begin{array}{l}\text { IX - Tynne Village } \\
\text { X - Lypnia St }\end{array}$} & \multirow{2}{*}{ Southwest } & 12 & 5100 & $0.030 \pm 0.002$ & $0.010 \pm 0.001$ & $0.017 \pm 0.001$ \\
\hline & & 11 & 2900 & $0.030 \pm 0.002$ & $0.010 \pm 0.001$ & $0.021 \pm 0.001$ \\
\hline XI - Kn. Olhy St & Southeast & 17 & 6050 & $0.050 \pm 0.003$ & $0.014 \pm 0.001$ & $0.029 \pm 0.001$ \\
\hline XII - Drahanchuka St & Southeast & 13 & 5100 & $0.048 \pm 0.003$ & $0.010 \pm 0.001$ & $0.024 \pm 0.001$ \\
\hline Average $(x \pm a)$ & & 167 & 64950 & $0.045 \pm 0.0028$ & $0.01 \pm 0.001$ & $0.028 \pm 0.001$ \\
\hline
\end{tabular}


(Ministerstvo Skhorony Zdorovia Ukrainy, 2007; Mohapatra \& Mohanty, 1994; Nersessian, 1992; Rosin, 1992; Sarto et al., 1987), since micronuclei are formed as a result of abnormal mitosis (Gorovaya \& Klimkina, 2002; Ajriyan, 1990; Schmid, 1975; Sladecek, 1965; Spang, 1996; Stich et al., 1982; Sugimura, 1982; Titenko-Holland, 1994; Theman, 1992; Tolbert et al., 1992; Watanabe et al., 1986; Watanabe et al., 1988a, b). Also, the absolute scatter data indicator has been calculated based on the value of the relative error.

Authors are encouraged to/should make readily reproducible materials described in the manuscript, including new software, databases and all relevant raw data, freely available to any scientist wishing to use them, without breaching participant confidentiality. In any case, authors should make their new software, databases, application / tool described in the manuscript available for testing by reviewers in a way that preserves the reviewers' anonymity.

\section{Results and discussion}

Rivne city is characterized by intense spills caused by stationary and especially removable sources, and their amount is greatly increased during the last decades (Klymenko \& Melikhova, 2001). There is a growth of background contamination in Rivne because of the cross-border transfers of pollutants, and it badly influences the condition of the city`s atmosphere and ecological state on the basis of mutagen background (Klymenko \& Melikhova, 2001).

Results of genetic bioassay for MN-test in the cells of the oral mucosa of pre-schoolers, which was held on 12 test ranges in city kinder gardens, are given in the Table 1. Number of surveyed children (boys and girls) in groups were shifting from 11 to 19 (average 13), and the total number of analyzing cells was from 2,900 to 64,950 . The data show that the maximum values of MN-

Table 2. Level of cells damage, state of children`s organism, the ecological situation on the grounds for CID indicator (Gorovaya et al., 1995; Gorovaya et al., 1996)

\begin{tabular}{|c|c|c|c|c|c|c|}
\hline $\begin{array}{l}\text { No. } \\
\text { of test } \\
\text { ground }\end{array}$ & $\begin{array}{l}\text { Number } \\
\text { of children }\end{array}$ & MN-index $\mathbf{x} \pm \mathbf{a}$ & CID & $\begin{array}{c}\text { Level } \\
\text { of cells } \\
\text { damage* }^{*}\end{array}$ & $\begin{array}{l}\text { State of children's } \\
\text { organism according to } \\
\text { the cytogenetic status" }\end{array}$ & $\begin{array}{c}\text { Ecological situation } \\
\text { on the basis } \\
\text { of mutagenic } \\
\text { background }\end{array}$ \\
\hline I & 12 & $0.037 \pm 0.001$ & 0.203 & $\begin{array}{c}\text { Below } \\
\text { average }\end{array}$ & Alarming & Satisfactory \\
\hline II & 14 & $0.033 \pm 0.002$ & 0.185 & $\begin{array}{l}\text { Below } \\
\text { average }\end{array}$ & Alarming & Satisfactory \\
\hline III & 14 & $0.024 \pm 0.001$ & 0.136 & Low & Safe & Satisfactory \\
\hline IV & 15 & $0.025 \pm 0.002$ & 0.138 & Low & Safe & Excellent \\
\hline $\mathrm{V}$ & 14 & $0.027 \pm 0.002$ & 0.152 & Low & Safe & Excellent \\
\hline VI & 19 & $0.034 \pm 0.001$ & 0.200 & $\begin{array}{l}\text { Below } \\
\text { average }\end{array}$ & Alarming & Satisfactory \\
\hline VII & 12 & $0.028 \pm 0.002$ & 0.153 & $\begin{array}{l}\text { Below } \\
\text { average }\end{array}$ & Alarming & Satisfactory \\
\hline VIII & 14 & $0.036 \pm 0.002$ & 0.199 & $\begin{array}{l}\text { Below } \\
\text { average }\end{array}$ & Alarming & Satisfactory \\
\hline IX & 12 & $0.017 \pm 0.001$ & 0.094 & Low & Safe & Excellent \\
\hline $\mathrm{X}$ & 11 & $0.021 \pm 0.001$ & 0.117 & Low & Safe & Excellent \\
\hline XI & 17 & $0.029 \pm 0.001$ & 0.163 & $\begin{array}{c}\text { Below } \\
\text { average }\end{array}$ & Alarming & Satisfactory \\
\hline XII & 13 & $0.024 \pm 0.001$ & 0.134 & Low & Safe & Excellent \\
\hline In all & 167 & $0.098 \pm 0.001$ & 0.156 . & $\begin{array}{c}\text { Below } \\
\text { average }\end{array}$ & Alarming & Satisfactory \\
\hline
\end{tabular}

Annotation: $\mathrm{P}_{\text {comfort }=0 .} \mathrm{P}_{\text {crysis=0.180. }}$ "Scale of evaluation of the condition of the bio systems and ecological situation on the basis of mutagenic background by methods suggested by Gorovaya (Gorovaya et al., 1995; Gorovaya et al., 1996). 
index on the test grounds reached 0,050 points, and their range of changes occurred between 0.03 and 0.05 (average $0.045 \pm 0.0023$ ). The highest maximum values of MNindices were found on I, V, VII, VIII, XI test grounds. Minimum MN-indices (X, IX, XII) did not exceed the values from 0.006 to 0.014 (average $0.01 \pm 0.001$ ). At the same time average values of the $\mathrm{MN}$ - index were changing from the low 0.017 to the highest 0.037 (aver- age $0.028 \pm 0.001)$. It is important to point out that the highest figures for average values of cytogenetic indices in the cells of the oral mucosa of children are inherent in the test grounds where there are fabrics and heavy traffic of vehicles, and where the $\mathrm{CO}$ content in the air exceeds MPC (Figs 1 and 2), and the lowest values were set for test grounds with one-story buildings (IX) and low intensity traffic.

Table 3. Scale of evaluation of condition of the bio systems and ecological situation on the basis of mutagenic background

\begin{tabular}{|c|c|c|c|c|}
\hline $\begin{array}{c}\text { Value of indicator } \\
\text { for MN-test }\end{array}$ & $\begin{array}{c}\text { Indicator of genetic } \\
\text { damage }\end{array}$ & $\begin{array}{c}\text { Level of genetic } \\
\text { damage }\end{array}$ & $\begin{array}{c}\text { Condition of the } \\
\text { bio systems }\end{array}$ & $\begin{array}{c}\text { Ecological situation on } \\
\text { the basis of mutagenic } \\
\text { background }\end{array}$ \\
\hline $0-0.027$ & $0-0,150$ & Low & Safe & Excellent \\
\hline $0.028-0.054$ & $0.151-0.300$ & Below average & Alarming & Unsatisfactory \\
\hline $0.055-0.081$ & $0.301-0.450$ & Average & Conflict & Unsatisfactory \\
\hline $0.082-0.108$ & $0.451-0.600$ & Above average & Threatening & Disastrous \\
\hline $0.109-0.135$ & $0.601-0.750$ & High & Critical & Disastrous \\
\hline $0.136-0.180$ & $0.751-1.000$ & Maximum & Dangerous & \\
\hline
\end{tabular}

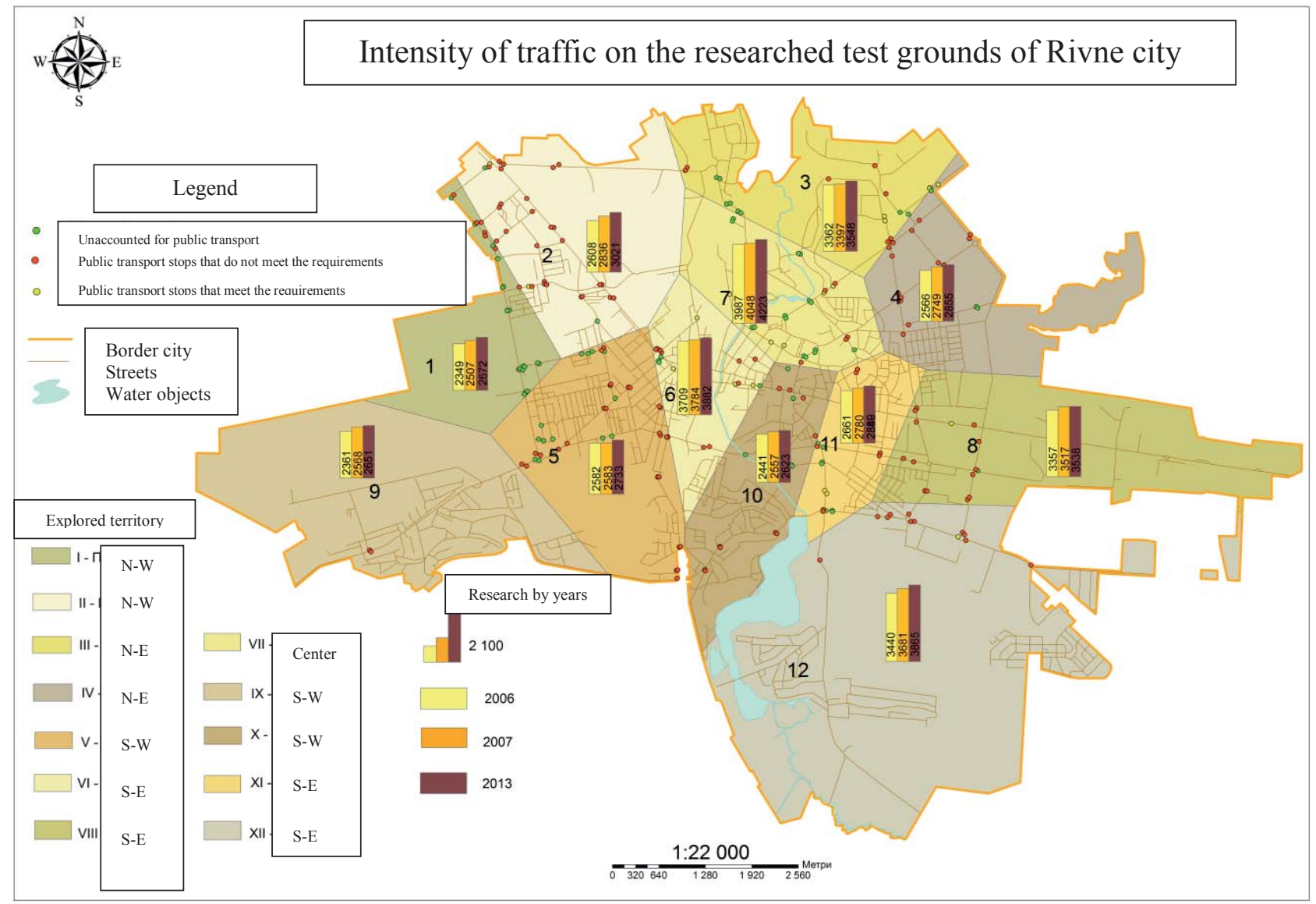

Figure 1. Intensity of traffic on the researched test grounds of Rivne city 
The basis of cytogenetic examination of the children of the city conditional indicators of damage (CID) were calculated with the purpose of defining the status of children, the level of cell damage and evaluation of the ecological situation on the test grounds.

In addition, on the basis of cytogenetic examination of the children of the city conditional indicators of damage (CID) were calculated with the purpose of defining the status of children, the level of cell damage and evaluation of the ecological situation on the test grounds (Table 2). Information presented in the Table 2 shows that the maximum values of CID set for I, VI i VIII test grounds $(0.203,0.20,0.199$ accordingly), and the lowest for IX (0.094) та X (0.117). CID values for other test grounds do not differ a lot and are shifting from 0.134 to 0.163 .

However, according to the scale of evaluation of the level of genetic damage (Table 3), condition of the biosystems and evaluation of the ecological situation on the basis of mutagenic background, the state of I, II, VI, VIII, $\mathrm{XI}$ test grounds was estimated as: «below average» for the level of cell damage; «alarming» for the state of children`s organisms according to the cytogenetic status; «satisfac- tory» - ecological situation on the basis of mutagenic background. At the same time on the test grounds IX, III, $\mathrm{XII}, \mathrm{X}$ the level of cell damage was estimated as «low», the state of children's organisms according to the cytogenetic status as «safe», and ecological situation on the basis of mutagenic background as «excellent» (Fig. 3).

The results of the researches show that according to the values of the $\mathrm{MN}$ - index of cells in the oral mucous membrane of pre-school children, the ecological situation on the basis of the mutagenic background of the area has changed from "excellent" to "satisfactory" (Fig. 4). Mutagenic background of the area, which got "satisfactory" status, is characterized by the growing anthropogenic load that is formed by total emissions of pollutants into the atmosphere.

Taking into consideration all above mentioned it has become clear that the deterioration of the ecological and genetic condition of the urban environment on the I, II, VI, VII, VIII, XI test grounds by the level of cell damage was "below average", the condition of the child's organism was "alarming" but the state of the environment has changed from "excellent" to "satisfactory". Doing such kind of researches can make it possible to observe the mu-

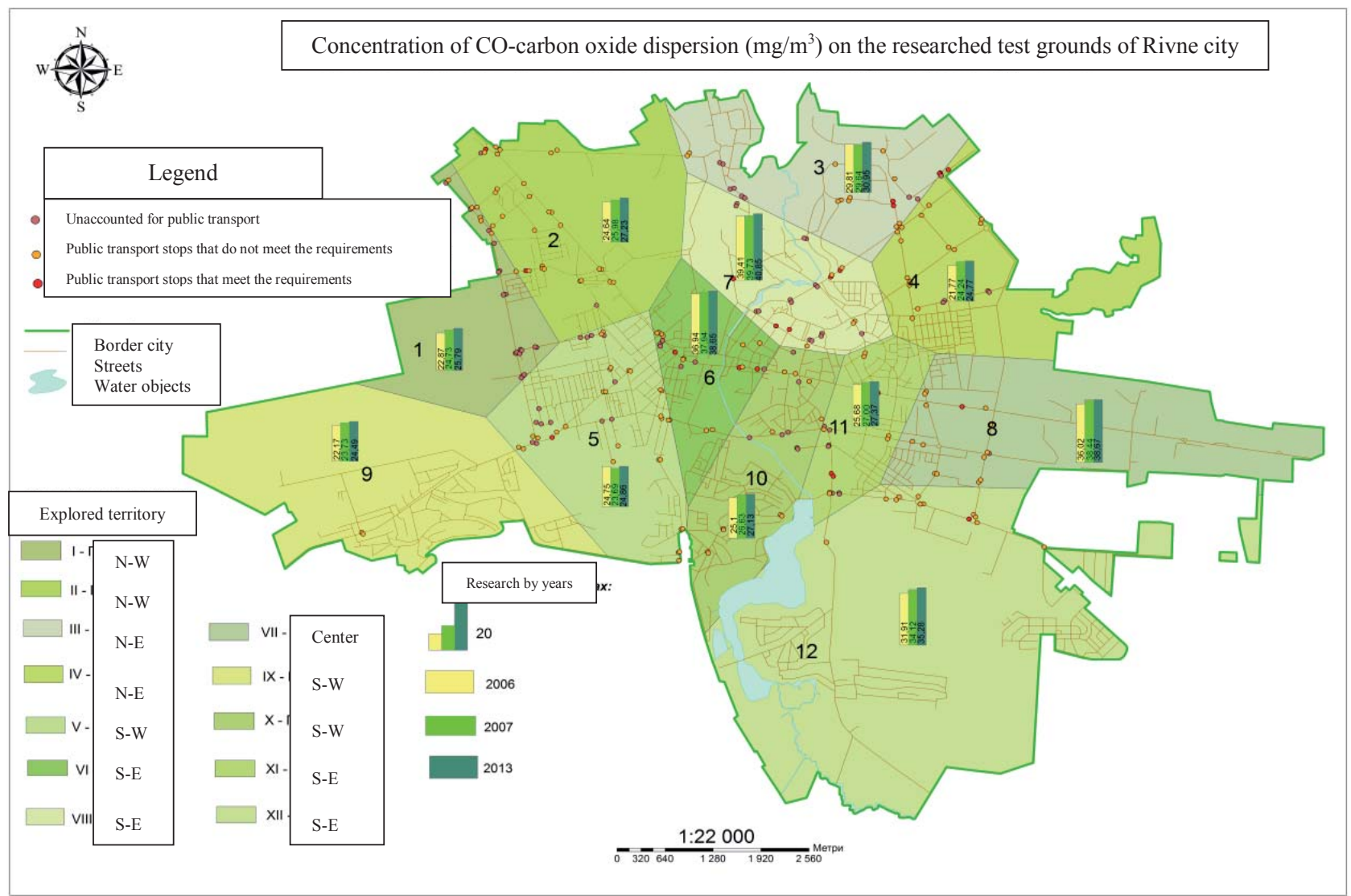

Figure 2. Concentration of CO-carbon oxide dispersion $\left(\mathrm{mg} / \mathrm{m}^{3}\right)$ on the researched test grounds of Rivne city 


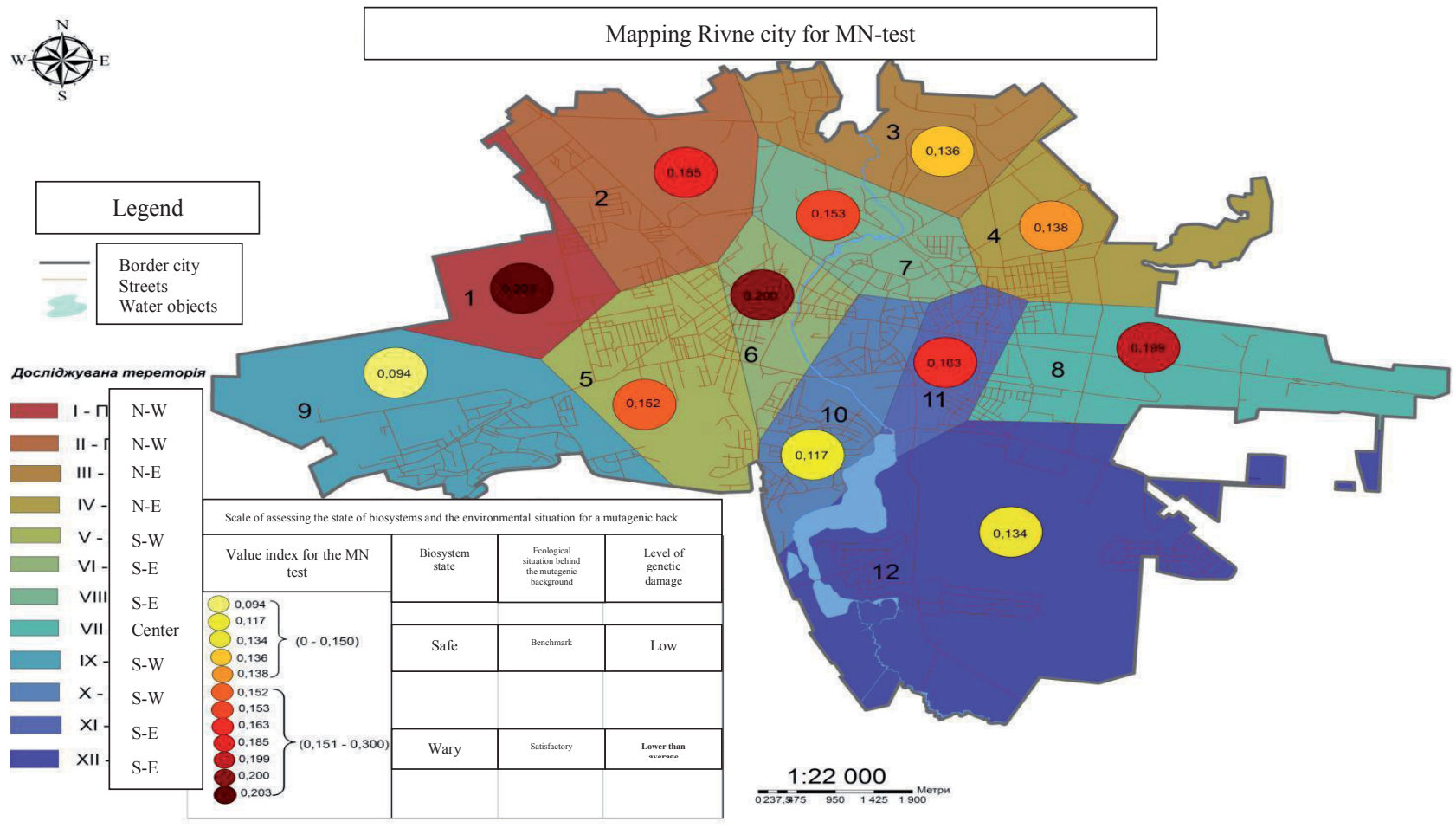

Figure 3. Mapping Rivne city for MN-test

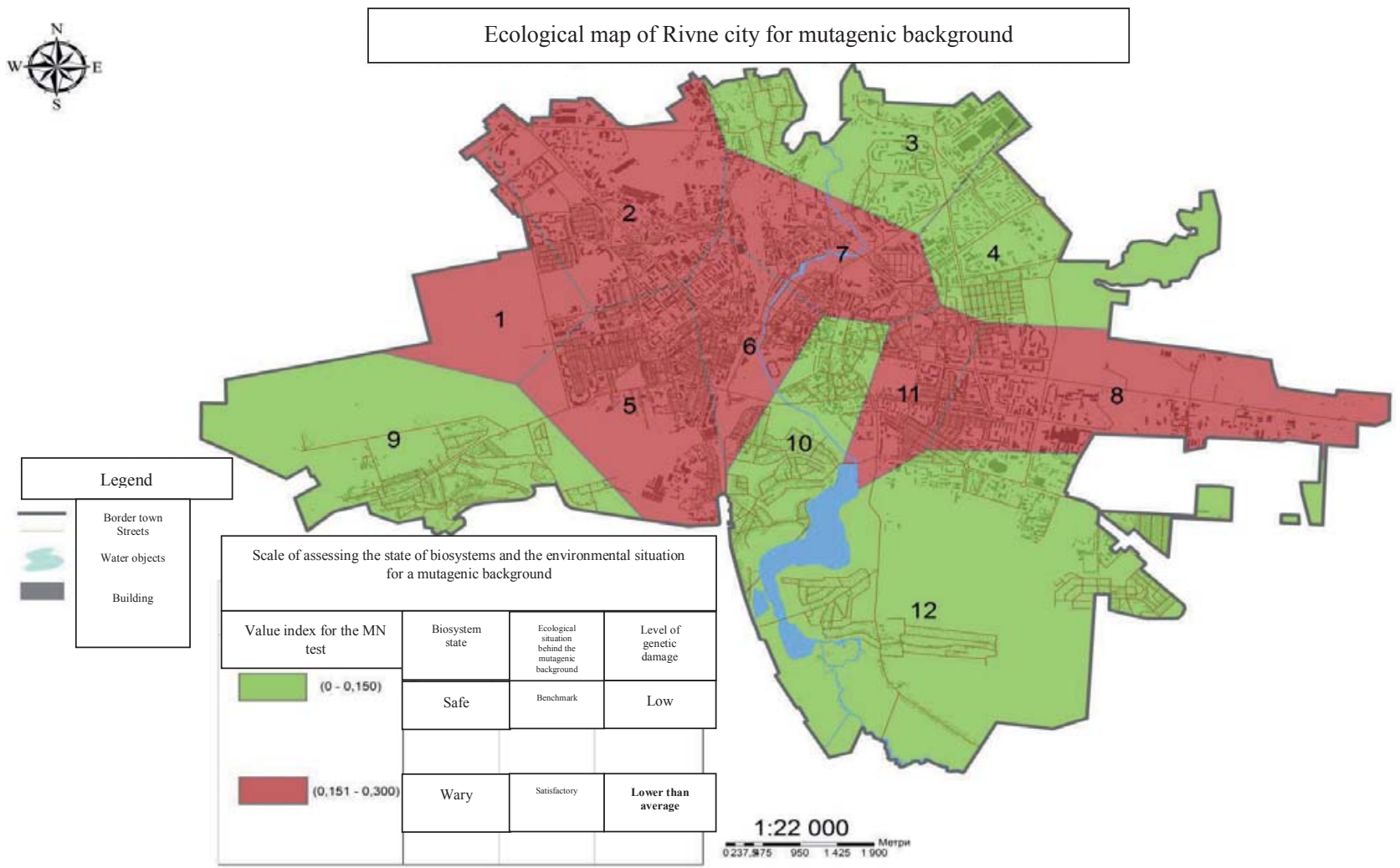

Figure 4. Ecological map of Rivne city for mutagenic background 
tagenic background of areas, genetic health, and genetic danger for humans because of harmful factors.

\section{Conclusions}

In this article there were described the laws of the nascence of micronuclei in cells of the oral mucosa of preschool children, who live on the test ranges with various technogenic loads, and according to the results of research such conclusions can be formulated:

1. The analysis of objects of harmful emissions from stationary and mobile sources in the city during the 1996-2013 years were made, and it showed their incessant growth. The volume of total emissions in 1996 was 13702 tons, and in 2011 it increased to 17,900 tonnes. The dynamics of harmful emissions into the atmosphere (from stationary and mobile sources and their amounts) is described by the progressive models that are the type of polynomial of 5th degree with a coefficient of determination over 0.75 . Average concentrations of pollutants are: phenol in 3.3; hydrogen fluoride 2.6; formaldehyde 3.3 MAC.

2. It was established that the concentrations of other pollutants (including heavy metals) were ranged from 0.1 to $0.7 \mathrm{MAC}$. The health status of population in recent decades has been deteriorating as a result of the growth of anthropogenic pressure and stress because of socio - economic crisis.

3. It was proved that the growth of spreading most diseases in the population of Rivne city is influenced by the growing volume of revenues of pollutants to the city's air from mobile sources.

4. It was found that using the micronucleus test in somatic cells of preschool children is appropriate for evaluating the overall environmental mutagenic background as a screening method.

5. It was proved that the maximum values of $\mathrm{MN}$-index on the test grounds reached 0.050 points, and their range of changes occurred between 0.03 and 0.05 (average $0.045 \pm 0.0023$ ). The highest maximum values of MN-indices were found on I, V, VII, VIII, XI test grounds. Minimum MN-indices (X, IX, XII) did not exceed the values from 0.006 to 0.014 (average $0.01 \pm 0.001$ ). Average values of the $\mathrm{MN}$ - index were changing from the low 0.017 to the highest 0.037 (average $0.028 \pm 0.001$ ). The maximum values of $\mathrm{MN}$-index on the basis of average value were found in the ranges I - (0.037); VI - (0.034); VIII - (0.036).

\section{References}

Ajriyan A.P., Oganesyan G.G. \& Arutyunyan R.M., 1990, Ocenka urovnya mikroyader v slizistoj rotovoj polosti bol'nyh allergozami i zdorovyh lic, prozhivayushchih $\mathrm{v}$ sel'skih mestnostyah [Evaluation of the level of micronuclei in the oral mucosa of patients with allergies and healthy individuals living in rural areas]. Biol. zhurn. Armenii 43(6): 528-529. (In Russian).

Ballarian C., Sarto F. \& Giacomelli L., 1992, Micronucleated cells in nasal mucosa of formaldehyde - exposed workers. Mutat. Res. 280(1): 1-7.

Bender J., 2002, The use of noncancer endpoints as a basis for establishing a reference concentration for formaldehyde. Regul. Toxicol. Pharmacol. 35: 23-31.

Cairns J., 1975, Mutation selection and the natural history of cancer. Nature 255: 197-200.

Chakrabarty R.H. \& Dutta K., 1988, Micronuclei test in routine smears from the uterine cervix. Eur. J. Gynecol. Oncol. 9(5): 370-372.

Feron V.J., Arts J.H., Kuper C.F., Slootweg P.J. \& Woutersen R.A., 2001, Health risks associated with inhaled nasal toxicants. Crit. Rev. Toxicol. 31: 313-347.

Gluck U. \& Gebbers JO., 2000, The comet assay of nasal epithelia: measurement of DNA damage in the assessment of genotoxic air pollution. Laryngoscope 110(1): 123-5.

Gorovaya A.I., Bobyr L.F., Skvorcova T.V. Digurko W.M. \& Klimkina I.I., 1995, Bioehkologicheskie kriterii ocenki mutagennogo fona i geneticheskogo riska dlya naseleniya promyshlennyh centrov Ukrainy [Bioecological criteria for assessing mutagenic background and genetic risk for the population of the industrial centers of Ukraine]. Sb. nauch. tr. konf. "Zdorov'e chelov.: tekhnol. formir. zdorov'ya v sisteme obrazov. i zdravoohran. Ukrainy". Dnepropetrovsk: 89-91. (In Russian).

Gorovaya A.I., Bobyr L.F., Skvortsova T.V., Digurko W.M. \& Klimkina I.I., 1996, Metodolohycheskye aspekty otsenky mutahennoho fona i henetycheskoho riska dlia cheloveka i bioty ot deistvyia mutahennykh ekolohycheskykh faktorov [Methodological aspects assessing mutagenic background and the genetic risk for humans and biota from external ecological factors of mutagenic activity]. Tsytolohyia i henetyka 6: 78-86. (In Russian).

Gorovaya A.I. \& Klimkina I.I., 2002, Ispol'zovanie citogeneticheskogo testirovaniya dlya ocenki ehkologicheskoj situacii i ehffektivnosti ozdorovleniya detej i vzroslyh prirodnymi adaptagenami [The use of cytogenetic testing to assess the ecological situation and the effectiveness of improving children and adults 
with natural adaptagens]. Dovkillya ta zdorov'ya 1(20): 47-50. (In Russian).

Goodnight C. \& Whitley L., 1961, Oligochaetes as indicators of pollution. Proc. 15th. Ind Waste Conf, Pardue Univ. Ext. 106: 139-142.

Gruter H., 1971, Radioactive fission product Cs-137 in mushrooms in W. Germany during 1963-1970. Health Physics. 20: 655-656.

Grazuleviciene R., 1995, Environmental study: particulate air pollution and asthma in Kaunas children population Host factors in Env. Epidemiology: Proceedings of the Conf. and Workshop. Jagiellonian Univ., Kraków: 193-201.

Gunneberg F., 1992, Changes in algae-fluorescence indicating toxic pollution. St. Theman. Cont. Remote Sens. Marine and Coastal Environ: Needs and Solut. Pollut. Monit. Confr. and Abatement. New Orleans, La, 167-170.

Haseman J.K. \& Hailey J.R., 1997, An update of the National Toxicology Program database on nasal carcinogens. Mutat. Res. 380: 3-11.

Horyna J. \& Randa Z.J., 1988, Uptake of radiocesium and alkali metals by mushrooms. Journal of Radioanalytical and Nuclear Chemistry 127: 107-120.

Klymenko M.O. \& Melikhova T.L., 2001, Dovidnyk ekolohichnoho stanu m. Rivne: navch. posibn. [Directory of the ecological state of Rivne: teaching. Manual]. Publish House Volynski oberehy, Rivne (In Ukrainian).

Kuper C.F., Woutersen R.A., Slootweg P.J. \& Feron V.J., 1997, Carcinogenic response of the nasal cavity to inhaled chemical mixtures. Mutat. Res. 380: 19-26.

Ministerstvo Okhorony Zdorovia Ukrainy Nakaz 13.03.2007 „Pro zatverdzhennia metodychnykh rekomendatsii" Obstezhennia ta raionuvannia terytorii za stupenem vplyvu antropohennykh chynnykiv na stan obiektiv dovkillia z vykorystanniam tsytohenetychnykh metodiv [Ministry of Health of Ukraine. Order of 13.03.2007 «On approval of methodological recommendations» Survey and zoning of the territory by the degree of influence of anthropogenic factors on the state of environmental objects using cytogenetic methods], 2007, MOZ, Kyiv. (In Ukrainian).

Mohapatra P.K. \& Mohanty R.C., 1994, Comparative toxicity of two pesticides to a greenagle. Chlorella vulgaris. Acta Botanica Hungarica. 1: 134-150.

Nair U., Obe G., Nair J. \& Maru G. B., 1991, Evaluation of Frequency of micronucleated oral mucosa cells as a marker for genotoxic in chewers of betel quid with or without tobacco. Mutat. Res. 261(2): 163-168.

Nersessian A.K., 1992, Activity of human carcinogens in the Salmonella and rodent bone marrow cytogenetic test. Mutat. Res. 281(4): 239-243.
Pantle K. \& Buck H., 1955, Die biologiste Uberwachung der Gewasser und die Darstellung der Ergebnisse Gas. Wassertach 96: 609-620.

Rosin M., 1992, The use of the micronucleus test on exfoliated cells to identify anticlastogenic action in humans. Mutat. Res. 287(2): 265.

Rosin M., 1992, The use of the micronucleus test on exfoliated cells to identify anticlastogenic action in humans. Mutat. Res. 287(2): 276.

Sarto F., Finotti S., Giacomelli L., Mazzotti D, Tomanin R \& Levis AG., 1987, The micronucleus assay in exfoliated cells of the human buccal mucosa. Mutagenesis 2(1): 11-17.

Schlegel H.F., MacGregor J.T. \& Everson R.B., 1986, Assessment of cytogenetic damage by quantitation of micronuclei in human peripheral blood erythrocytes. Cancer. Res. 46: 3717-3721.

Schmid W., 1975, The micronucleus test. Mutat. Res. 31(1): 9-15.

Serdiuk A.M., 1996, Ekolohichna bezpeka Ukrainy [Ecological safety of Ukraine]. Dovkillia ta zdorov`ia 1: 4-7. (In Ukrainian).

Sladecek V., 1965, The future of the saprobity system. Hydrobiologia 25: 518-37.

Sladecek V., 1973, System of water quality from the biological point of view. Arch. Hydrobiol. Ergeb. Limnol. 7: 218-219.

Spang W.D., 1996, Bioindikation in Rahmen raumrelevanter Planungen Grundlagen, Bedeutung, Indikatorwahl. Heidelberg, Geogr. Arb. 100: 75-87.

Shirasu Y., Moriya M. Tezuka H., Teramoto S., Ohta T., Inoue T., 1982, Mutagenicity screening studies on pesticides. Environmental mutagens and carcinogens. Tokyo, New York: 331-335.

Stich H.F., Curtis J.R. \& Parida B.B., 1982, Application of micronucleus test to exfoliated cells of high cancer risk groups: tobacco chewiers. Int. J. Cancer. 30: 553559.

Sugimura T.A., 1982, View of a caneer researches on environmental mutagens. Environmental mutagens and carcinogens. Tokyo, New York: 3-20.

Titenko-Holland N., 1994, Mesuarement and characterization of micronuclei in exfoliated human cells by fluorescence in situ hybridization with a centromeric probe. Mutat. Res. 1: 39-50.

Theman., 1992, Cont. Remote Sens. Mar and Coastal Environ: Needs and Solut. Pollut. Monit. Confr. and Abatement. New Orleans, La, June, 167-170.

Tolbert P.E., Shy C.M. \& Allen J.W., 1992, Micronuclei and other nuclear anomalies in buccal smears: method development. Mutat. Res. 271(1): 69-77.

Tymchenko O.I. \& Serdiuk A.M., 1996, Pro otsinku vplyvu chynnykiv navkolyshnoho seredovyshcha na suspilne zdorovia naselennia Ukrainy Urbanizovane 
navkolyshnie seredovyshche: okhorona pryrody ta zdorovia liudyny [On the assessment of the impact of environmental factors on the health of the population of Ukraine Urban environment: the protection of nature and human health]. NU, Kyiv: 7-11. (In Ukrainian).

Watanabe T., Asai K., Houki A., Tanaka S., Hizuka T., 1986, Saprophilous and eurysaprobic diatom taxa to organic water pollution and diatom assemblage index (DAIpo). Diatom 2: 23-73.
Watanabe T., Asai K. \& Houki A., 1988a, Biological information.closely related to the numerical index DAIpo (Diatom Assemblage Index to Organic Water Pollution). Diatom 4: 49-58.

Watanabe T., Asai K. \& Houki A., 1988b, Numerical water quality monitoring of organic pollution using diatom assemblages. 9th Diatom Symposium. Frank Round Press, Bristol, UK: 123-141. 